\title{
A population estimate of the Sooty Shearwater Puffinus griseus in the Wollaston and Hermite Island Groups, Cape Horn Archipelago, Chile, and concerns over conservation in the area
}

Estimación poblacional de fardela negra Puffinus griseus en Islas del Grupo Wollaston y Hermite, Archipiélago Cabo de Hornos, Chile y consideraciones para la conservación del área

\section{R. Paul Scofield ${ }^{1,2}$ and Ronnie Reyes-Arriagada ${ }^{3}$}

\author{
${ }^{1}$ Zoology Department, University of Otago, Box 56, Dunedin, New Zealand \\ ${ }^{2}$ Present address: Canterbury Museum, Rolleston Avenue, Christchurch, New Zealand \\ ${ }^{3}$ Instituto de Ciencias Marinas y Limnológicas, Facultad de Ciencias, Universidad Austral de Chile, Casilla 567, Valdivia, \\ Chile.ronnie.reyes@uach.cl
}

\begin{abstract}
We documented the population size of Sooty Shearwater on the Wollaston and Hermite Island Groups. A population of at least 100,000 pairs were found on Wollaston and there may be as many as 300,000 pairs in the Wollaston and Hermite Island Groups. We also confirmed the presence of Magellanic Diving-petrel and Fuegian Storm-petrel in the Island Group and discussed the status of these taxa in southern Chile. The status of the mammals found on these islands is also summarised and concerns are raised over the possibility that introduced mammals, especially beavers, muskrats, minks and feral cats may reach these pristine islands affecting seabird populations.
\end{abstract}

Key words: Cape Horn, Pelecanoides magellani, Oceanites oceanicus chilensis, introduced species

\section{INTRODUCTION}

Recent studies have reported significant declines in the Sooty Shearwater Puffinus griseus (Gmelin, 1789) populations, not only at their New Zealand breeding grounds (Scott et al. 2008) but also on migration (Scofield \& Christie 2002) and at their non-breeding grounds (Veit et al. 1997). The status of seabirds on the Tierra del Fuego islands in southern Chile and Argentina are poorly known (Schlatter 1984). In the past 20 years work has been done on terrestrial birds (e.g., Venegas 1981, 1991) of the area but little has been published on seabirds since the 1930s. The discovery of a huge Rockhopper Penguin colony (Eudyptes chrysocome Forster, 1781) on Staten Island (Schiavini 2000), together with large colonies of Blackbrowed Albatross (Thalassarche melanophris Temminck, 1828) on Noir Island (Clark et al. 1984a) suggests that more is still to be discovered on these remote islands.

Sooty shearwaters breeding colonies were first confirmed on the southern uplands of Wollaston Island in December 1915 (Beck 1918). At the end of 1932 the species was recorded breeding and considered to be exceedingly common on Wollaston and Bayly Islands (Reynolds 1935). Following a gap of $\sim 50$ years, Clark et al. (1992) found Sooty Shearwaters breeding on Ildefonso Island, Hornos, Wollaston and Sesambre Islands in 1984 and 1985. Outside the Cape Horn group, Clark et al. (1984b) found a very large colony of Sooty Shearwaters on Guafo Island (43⒊ $36^{\prime} \mathrm{S}, 74^{\circ} 43^{\prime} \mathrm{W}$ ) and a smaller colony

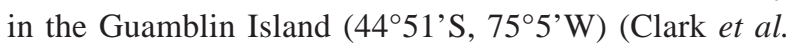
1984a, Reyes-Arriagada et al. 2007).

Here we document the population size of Sooty Shearwater on the Wollaston and Hermite Island Groups. Due to the scarce amount of information existing for the Magellanic Diving-petrel Pelecanoides magellani (Mathews, 1912) and the Fuegian Storm-petrel Oceanites oceanicus chilensis (Murphy, 1936), two endemic small petrel taxa of this area, we also briefly summarize what is known about their distribution and biology. 


\section{MATERIALS AND METHODS}

\section{STUDY SITES}

The Wollaston and Hermite Groups consist of 10 large islands and 30 small stacks with a total area of 65,000 ha (Fig. 1). On $18^{\text {th }}$ and $19^{\text {th }}$ December 2000 we visited 2 of the 10 islands: Wollaston Island and Epave Island, and made remote observations of Middle Island. Wollaston Island ( $55^{\circ} 43^{\prime} \mathrm{S}, 67^{\circ} 22^{\prime} \mathrm{W}$ ) is the largest island in the group ( $673 \mathrm{~m}$, 21,440 ha), primarily vegetated with Magellanic moorland with stands of evergreen Nothofagus betuloides (Mirb.) Oerst. Montane cushion communities predominate above $300 \mathrm{~m}$. Middle Island ( $26 \mathrm{ha},<150 \mathrm{~m}, 55^{\circ} 36^{\prime} \mathrm{S}, 67^{\circ} 19^{\prime} \mathrm{W}$ ) is situated less than $500 \mathrm{~m}$ offshore at the south end of Middle Cove on Wollaston Island. This island has forest vegetation similar to Wollaston Island. Epave Island (60 ha, $<50 \mathrm{~m}$ A.S.L., $55^{\circ} 49^{\prime} \mathrm{S}, 6^{\circ} 22^{\prime} \mathrm{W}$ ) is in the Franklin Channel that separates Wollaston and Hermite Islands. It is primarily vegetated by Magellanic moorland with a small area of stunted $N$. betuloides forest on the south and eastern-sides.

\section{DENSITY OF BURROWS OF SOOTY SHEARWATER}

During this study, a total of $19810 \times 10 \mathrm{~m}^{2}$ quadrats were placed randomly and examined through areas of forest on Wollaston Island, counting all the burrows found. To estimate the area of the colony, the distribution of forest in the Wollaston Island Group was taken from a satellite photograph taken in 1996 (Source: Canada Centre for Remote Sensing of the Canadian Space Agency). Estimates are presented as mean \pm SD. Occupancy was assessed by recording faeces, signs of digging and by using smell. We also used long sticks stuck into the burrows to feel birds and also put our hands down the burrow to grab and remove the occupant.

\section{Results AND Discussion}

\section{Population estimates of Sooty Shearwater}

Large numbers of burrows were found in the small stunted $N$. betuloides forests between 100 and $300 \mathrm{~m}$ A.S.L. on Wollaston Island. The density of burrows in the forest was estimated to be $0.105 \pm 0.189$ burrows $\mathrm{m}^{-2}$. Although

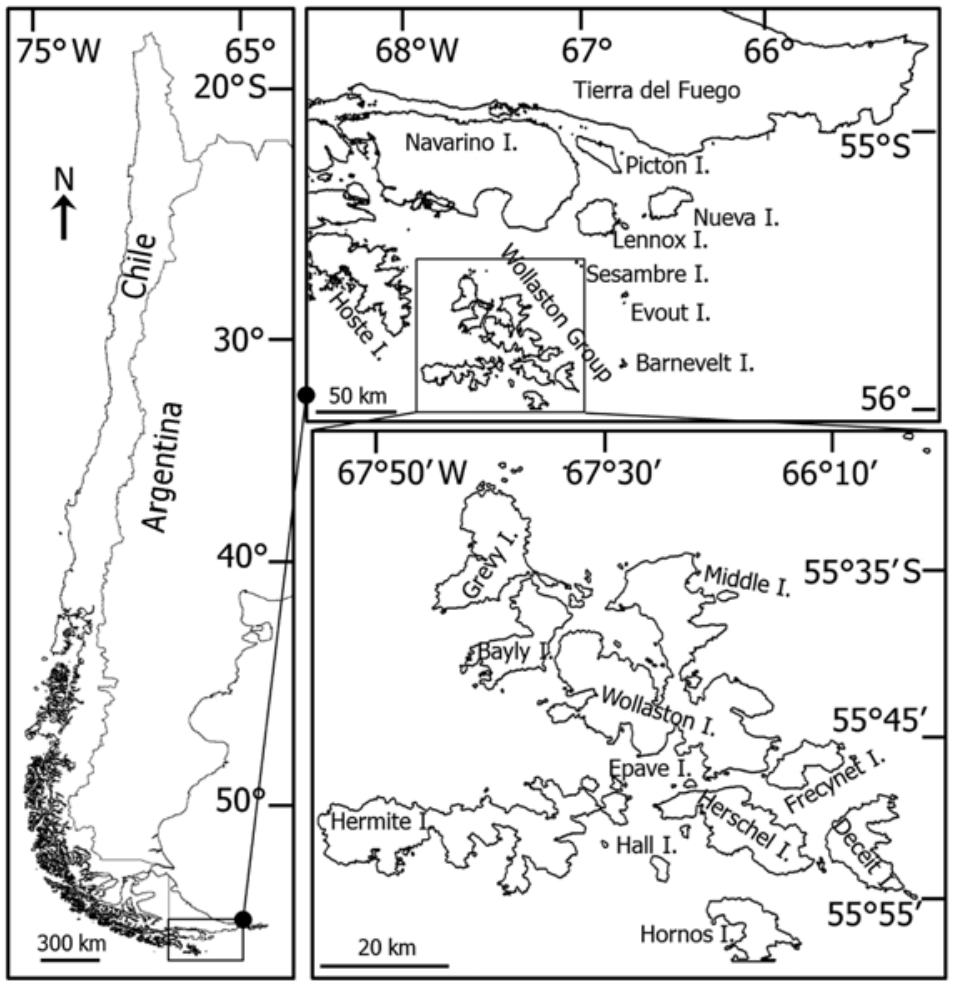

Figure 1. Location of Wollaston and Hermite Island Groups, Cape Horn Archipelago, Chile / Ubicación de las islas del Grupo Wollaston y Hermite, Archipiélago Cabo de Hornos, Chile 
the bulk of the island is not covered by forest but Magellanic moorland, we estimated that the area surveyed was 4998 ha (or 23\% of the island) and contained 568 ha of suitable forest above $100 \mathrm{~m}$. Thus, we estimate that this area contained about 59,000 burrows. We estimated that $60 \%$ of burrows found were in use during the period of the census or had been prospected during the spring of 2000. However only 4 of 150 burrows examined were occupied during the day. This is probably as our visit coincided with the species 'honeymoon' period when most breeding birds are away from the island (Warham 1990). If we assume that each of the used burrows was laid in (shortly after our visit), there would be about 35,500 breeding pairs of sooty shearwater in the study area. This estimate is supported by the fact that in the late evening hundreds of birds were seen flying over the inland.

Sooty shearwaters are documented as breeding at forested sites on the southern half of Wollaston Island (Beck 1918, Reynolds 1935, Clark et al. 1992), thus we suggest that the density of burrows as reported for this location is similar elsewhere on the island. Satellite photographs enable us to estimate that approximately 1600 ha of forest exists on Wollaston Island above $100 \mathrm{~m}$. Thus we estimate that approximately 166,500 Sooty Shearwater burrows exist on Wollaston Island. With a $60 \%$ occupancy rate based on estimates using signs of occupancy we estimate that approximately 100,000 breeding pairs may be present above $100 \mathrm{~m}$. There may be a small number of shearwaters breeding below $100 \mathrm{~m}$ (Reynolds 1935), but none were found during this survey.

On Epave Island, recently occupied Sooty Shearwaters burrows were found on the eastern side of the island below $100 \mathrm{~m}$, whereas occupied burrows of Fueguian Storm-Petrel were found in the cushion plants (Table 1) near sea level and may occur all the way to the summit. Burrows containing light blue feathers that almost certainly belonged to Blue Petrel Halobaena caerulea (Gmelin, 1789) were also found. Unoccupied burrows of Magellanic Diving-petrel recognised by the reddish faeces at the entrance and the presence of two primaries feathers found outside one burrow were found in thick Hebe elliptica (Forster) on the southwest corner of the island.

Table 1. The status of procellarids Seabirds on the Wollaston and Hermite Island Groups / Estado de aves marinas proceláridas en islas del Grupo Wollaston y Hermite

\begin{tabular}{|c|c|c|c|c|}
\hline Island & Sooty Shearwater & Fueguian Storm-Petrel & Magellanic Diving-Petrel & Blue Petrel \\
\hline Wollaston & 100,000 (This study) & $\begin{array}{l}\text { Undetermined number } \\
\text { (Reynolds 1935) }\end{array}$ & & \\
\hline Epave & 6 (This study) & 10 (This study) & 2 (This study) & 8 (This study) \\
\hline Middle & Small group on land & & & \\
\hline Frecynet & & $\begin{array}{l}\text { Not confirmed (Reynolds 1935, } \\
\text { Murphy 1936) }\end{array}$ & & \\
\hline Herschel & $\begin{array}{l}\text { Abundant prehistorically } \\
\text { (Legoupil 1994, Lefèvre 1997) }\end{array}$ & $\begin{array}{l}\text { Undetermined number } \\
\text { (Reynolds 1935) }\end{array}$ & & \\
\hline Deceit & Large numbers (Reynolds 1935) & $\begin{array}{l}\text { Undetermined number } \\
\text { (Reynolds 1935) }\end{array}$ & $\begin{array}{l}\text { Undetermined number } \\
\text { (Reynolds 1935) }\end{array}$ & \\
\hline Hall & & $\begin{array}{l}\text { Not confirmed (Reynolds 1935, } \\
\text { Murphy 1936) }\end{array}$ & $\begin{array}{l}\text { Undetermined number } \\
\text { (Clark et al. 1992) }\end{array}$ & \\
\hline Bayly & $\begin{array}{l}\text { Abundant prehistorically } \\
\text { (Legoupil 1994, Lefèvre 1997) }\end{array}$ & & & \\
\hline Hornos & $\begin{array}{l}\text { Small numbers (Clark et al. } \\
\text { 1992) }\end{array}$ & & & \\
\hline Grevy & $\begin{array}{l}\text { Abundant prehistorically } \\
\text { (Legoupil 1994, Lefévre 1997) }\end{array}$ & & & \\
\hline Total & 300,000 (This study) & Undetermined & Undetermined & Undetermined \\
\hline
\end{tabular}


The Wollaston and Hermite Island Groups make up 65,000 ha and the Cape Horn National Park is 63,093 ha. We estimate these islands contain about 4800 ha of suitable forest over $100 \mathrm{~m}$. We consider it likely that Sooty Shearwaters occupy all suitable habitats on all islands of the Wollaston Group. If the density and occupancy of burrows is similar on all islands in the group to that on the northern part of Wollaston Island we estimate approximately 300,000 pairs breed in the Wollaston Group.

\section{Status OF THE TWO ENDEMiC BREEDING PETRELS OF SOUTHERN CHILE}

Both the Magellanic Diving-petrel and the Fuegian Stormpetrel are common in many places in the fjords. However, their breeding habits are poorly known due to the scattered and cryptic nature of their burrows. Outside Wollaston Group (Table 1), records of Magellanic Divingpetrel breeding are only confirmed on a small island south of Puerto Toro, Navarino Island (Reynolds 1935), with specimen records from islands west of the Cockburn Channel, London Island, Islet Antonio in Trinidad Channel (Murphy 1936). The status of Fuegian Storm- petrel has recently been reaffirmed by Palma et al. (2012). Outside Wollaston Group (Table 1), possible breeding sites are on Chanticler, Hoste and Ildefonso Islands (Reynolds 1935, Murphy 1936). There are some records from Gable Island in the Beagle Channel (Oustalet 1891) and Morton Island (Roberts 1940).

\section{INTRODUCED MAMMALS OF THE WOLLASTONARCHIPELAGO}

Non-native mammal species were recently introduced to the Wollaston Archipelago (Table 2). Brown Rat [Rattus rattus (Linnaeus, 1758)] and House Mouse (Mus musculus Linnaeus, 1758) have only been recorded from the Wollaston and Hermite Groups since $1978^{1}$. American mink [Mustela vison (Schreber, 1777)] and muskrat [Ondatra zibethicus (Linnaeus, 1766)] have recently spread to Navarino and Hoste Island (Anderson et al. 2006, Valenzuela et al. 2013a, b; 2014) and mink to Lennox Islands (Davis et al. 2012). Their potential to colonize new areas, in our opinion, makes both species the most significant threat for seabirds in the Wollaston and Hermite Island Groups through predation and/or competition with native species.

Table 2. List of native mammal species found and mammal species that could potentially be introduced to the Wollaston and Hermite Island Groups / Lista de especies de mamíferos nativos encontrados y especies de mamíferos que pueden potencialmente ser introducidos en Islas del Grupo Wollaston y Hermite

\begin{tabular}{lll}
\hline Scientific name & Common name & Status \\
\hline Native species & & \\
Lontra felina (Molina, 1782) & Marine Otter & Present \\
L. provocax (Thomas, 1908) & Southern River Otter & Present \\
Akodon hershkovitzi (Patterson, Gallardo \& Freas, 1984) & Hershkovitz's Grass Mouse & Present \\
Oligoryzomys magellanicus (Bennet, 1836) & Magellanic Pygmy Rice Rat & Present \\
Euneomys chinchilloides (Waterhouse, 1839) & Patagonian Chinchilla Mouse & Present \\
Introduced species & & \\
Neovison vison (Schreber, 1777) & American Mink & Absent \\
Ondatra zibethicus (Linnaeus, 1766) & Muskrat & Absent \\
Rattus norvegicus (Berkenhout, 1769) & Brown Rat & Absent \\
Rattus rattus (Linnaeus, 1758) & House Rat & Absent \\
Mus musculus (Linnaeus, 1758) & House Mouse & Present \\
Canis hupus familiaris (Linnaeus, 1758) & Domestic dog & Present as pet \\
Felis catus (Linnaeus, 1758) & Domesticated cats & Absent \\
Oryctolagus cuniculus (Linnaeus, 1758) & European Rabbit & Absent \\
Castor canadensis (Kuhl, 1820) & American Beaver & Absent \\
\hline
\end{tabular}

\footnotetext{
${ }^{1}$ Charles Porter and Cristian Donoso, personal communication
} 
Domestic dogs were present at the naval base at Ross Cove and Hornos Island during the field work. The faeces of these individuals contained murid fur and Magellanic penguin feathers. The impact of these predators on other seabird species is unknown. Domesticated cats are kept in military outposts and ranches throughout the archipelago and on Navarino Island (Anderson et al. 2006) and may cause a significant impact to seabird populations through predation (Warham 1990). North American Beavers (Castor canadensis Kuhl, 1820) have also spread to Navarino, Hoste, Nueva, Picton and Lennox Island since the 1940's (Anderson et al. 2006). Beaver's selfintroduction to the Cape Horn Islands would severely impact the forest community through habitat destruction.

\section{CONCERN FOR THE CONSERVATION STATUS OF THE Wollaston AND Hermite IsLAND Groups}

These islands have a remarkable and virtually pristine flora and fauna. It is of concern that the introduced mammals, in particular beavers, minks, feral cats and rats may invade these unique sanctuaries. We recommend that the Chilean Government should give and enforce National Park status to these islands. This would help to prevent illegal landings and allow monitoring of the islands, and also in the preparation of contingency plans against the invasion or introduction of unwanted predators.

\section{AcKnowledgments}

We thank the Armada de Chile and especially the officers and crew of the Patrol Vessel «Mikalvi» and the staff of the Local Maritime Authority Islas Wollaston, Ross Cove for their hospitality. We thank Sgto. Gutiérrez from Local Maritime Authority Cabo de Hornos, Sgto. Retamal from Local Maritime Authority Islas Wollaston, geologist Charles Porter and explorer Cristian Donoso, for recent information about presence of native and introduced mammals on the Archipelago. We thank Alejandro Valenzuela for giving us information concerning impacts of Chilean mammals on seabirds. This research was made possible through a grant from the New Zealand Vicechancellors Committee's Claude McCarthy Fellowship fund. Work was carried out with the support of the Corporación Nacional Forestal, CONAF (permit 16/02, 2000).

\section{LITERATURE CITED}

Anderson CB, R Rozzi, JC Torres-Mura, SM McGehee, MF Sherriffs, E Schüttler \& AD Rosemond. 2006. Exotic vertebrate fauna in the remote and pristine sub-Antarctic Cape Horn Archipelago, Chile. Biodiversity and Conservation 15: 3295-3313.

Beck RH. 1918. Narrative of a bird quest in the vicinity of Cape Horn. American Museum Journal, United States 18: 111-119.

Clark GS, A Cowan, P Harrison \& WRP Bourne. 1992. Notes on the seabirds of the Cape Horn Islands. Notornis 39: 133-144.

Clark GS, AJ Goodwin \& AP Von Meyer. 1984a. Extension of the known range of some seabirds on the coast of southern Chile. Notornis 31: 320-334.

Clark GS, AP Von Meyer, JW Nelson \& JN Watt. 1984b. Notes on sooty shearwaters and other avifauna of the Chilean offshore island of Guafo. Notornis 31: 225-231.

Davis EF, CB Anderson, AEJ Valenzuela, JL Cabello \& N Soto. 2012. American mink (Neovison vison) trapping in the Cape Horn Biosphere Reserve: enhancing current trap systems to control an invasive predator. Annales Zoologici Fennici 49: 18-22.

Lefèvre C. 1997. Seabird fowling in southern Patagonia: a contribution to understanding the nomadic round of the Canoeros Indians. International Journal of Osteoarchaeology 7: $260-270$

Legoupil D. 1994. El archipiélago del Cabo de Hornos y la costa sur de la isla Navarino: poblamiento y modelos económicos. Anales del Instituto de la Patagonia 22: 101121.

Mattern T, U Ellenberg, G Luna-Jorquera. 2002. A South American Marine Otter Lontra felina preys upon chicks of the Peruvian Diving Petrel Pelecanoides garnotii. Marine Ornithology 30: 95-96.

Murphy RC. 1936. Oceanic birds of South America. American Museum of Natural History, New York.

Oustalet E. 1891. Oiseaux. In: Mission Scientifique de Cap Horn 1882-1883. Zoologie 6 (B): 1-341.

Palma RL, AJD Tennyson, CP Gaskin \& A Jaramillo. 2012. The scientific name, author, and date for the «Fuegian stormpetrel», a subspecies of Oceanites oceanicus from southern South America. Notornis 59: 74-78.

Reynolds PW. 1935. Notes on the birds of Cape Horn. Ibis 77: 65-101.

Reyes-Arriagada R, P Campos-Ellwanger, RP Schlatter \& C Baduini. 2007. Sooty Shearwater (Puffinus griseus) on Guafo Island: the largest seabird colony in the world?. Biodiversity and Conservation 16: 913-930.

Roberts B. 1940. The life cycle of Wilson's Storm Petrel Oceanites oceanicus (Kuhl). British Graham Land Expedition 1934-37. Scientific Report, United Kingdom 1: 141-194. 
Robertson CJR \& BD Bell. 1984. Seabird status and conservation in the New Zealand Region. In: Croxall JP, PGH Evans \& RW Schreiber (eds). Status and conservation of the world's seabirds, pp. 573-586. Technical Publication 2, International Council for Bird Protection, Cambridge.

Schiavini ACM. 2000. Staten Island, Tierra del Fuego: The largest breeding ground for southern rockhopper penguins? Waterbirds 23: 286-291.

Schlatter RP. 1984. The Status and Conservation of Seabirds in Chile. In: Croxall JP, PGH Evans \& RW Schreiber (eds). Status and conservation of the world's seabirds, pp. 261269. Technical Publication 2, International Council for Bird Protection, Cambridge.

Scofield RP \& D Christie. 2002. Beach patrol records indicate a substantial decline in Sooty Shearwater, Puffinus griseus numbers. Notornis 49: 158-165.

Scott D, RP Scofield, CM Hunter \& D Fletcher. 2008. Decline of Sooty Shearwaters, Puffinus griseus, on The Snares, New Zealand. Papers and Proceedings of the Royal Society of Tasmania 142: 185-196.

Valenzuela AEJ, A Raya-Rey, L Fasola, RA Sáenz Samaniego \& A Schiavini. 2013a. Trophic ecology of a top predator colonizing the southern extreme of South America: feeding habits of invasive American mink
(Neovison vison) in Tierra del Fuego. Mammalian Biology 78: 104-110.

Valenzuela AEJ, A Raya-Rey, L Fasola \& A Schiavini. 2013 b. Understanding the inter-specific dynamics of two co-existing predators in the Tierra del Fuego Archipelago: the native southern river otter and the exotic American mink. Biological Invasions 15: 645-656.

Valenzuela AEJ, CB Anderson, L Fasola \& JL Cabello. 2014. Linking invasive exotic vertebrates and their ecosystem impacts in Tierra del Fuego to test theory and determine action. Acta Oecologica 54: 110-118. <http:// dx.doi.org/10.1016/j.actao.2013.01.010>

Veit R, J McGowan, D Ainley, T Wahls \& P Pyle. 1997. Apex marine predator declines ninety percent in association with changing oceanic climate. Global Change Biology 3: 23-28.

Venegas C. 1981. Aves de las Islas Wollaston y Bayly, Archipiélago del Cabo de Hornos. Anales del Instituto de la Patagonia 12: 213-219.

Venegas C. 1991. Ensambles avifaunísticos estivales del Archipiélago Cabo de Hornos. Anales del Instituto de la Patagonia 20: 69-82.

Warham J. 1990. The petrels: their ecology and breeding systems, 614 pp. Academic Press, London.

Received 27 November 2012 and accepted 22 July 2013

Associate Editor: Maritza Sepúlveda M. 